\title{
TRI N (NITENI, NIROAKE, NAMBAHAKE) DALAM MENGEMBANGKAN KREATIVITAS SISWA SEKOLAH DASAR
}

\author{
Ana Fitrotun Nisa ${ }^{1}$; Zuhdan Kun Prasetyo ${ }^{2}$; Istiningsih ${ }^{3}$ \\ ${ }^{1}$ Universitas Sarjanawiyata Tamansiswa; ${ }^{2}$ Universitas Negeri Yogyakarta; ${ }^{3}$ UIN Sunan Kalijaga Yogyakarta \\ Email: ${ }^{1}$ ananisa@ymail.com, ${ }^{2}$ zuhdan@uny.ac.id, ${ }^{3}$ istiningsih81@gmail.com
}

\begin{abstract}
Abstrak: Perkembangan zaman menuntut semua pihak memiliki sikap kreatif. Pendidikan merupakan salah satu aspek yang harus peka terhadap perubahan zaman.Pendidikan dasar (Sekolah Dasar) memiliki peranan yang sangat penting dalam mengembangkan sikap kreatif siswa sejak dini. Salah satu alternatif cara yang dapat dilakukan untuk mengembangkan sikap kreatif adalah dengan mengimplementasikan ajaran Tri $\mathrm{N}$ (niteni, niroake, nambahake) dalam proses pembelajaran. Tri $\mathrm{N}$ merupakan salah satu ajaran Tamansiswa yang digunakan oleh Ki Hadjar Dewantara dalam proses pembelajaran. Artikel ini bertujuan untuk memaparkan implementasi ajaran Ki Hadjar Dewantara yang berupa Tri N dalam meningkatkan kreativitas siswa melalui pembelajaran IPA di SD. Jenis penelitian ini merupakan penelitian kualitatif deskriptif dengan subjek sebanyak 70 siswa dan tiga guru. Teknik pengumpulan data dilakukan dengan teknik observasi, rubrik pengamatan sikap kreatif, wawancara dan dokumentasi.Teknik analisis data menggunakan teknik analisis Milles and Huberman yang terdiri dari reduksi data, penyajian data dan penarikan kesimpulan (verifikasi).Hasil penelitian yang telah dilakukan menunjukkan bahwa dengan mengimplementasikan ajaran Tri $\mathrm{N}$ menjadikan siswa memiliki kreativitas tinggi sehingga mampu menghasilkan karya-karya yang inovatif yang menjadikan bekal bagi siswa untuk mampu menyesuaikan diri dengan perkembangan zaman yang ada.
\end{abstract}

Kata Kunci: Tri N, pembelajaran IPA, kreativitas, Sekolah Dasar.

\section{PENDAHULUAN}

Proses pendidikan yang dilakukan di Sekolah Dasar (SD) merupakan pondasi yang akan dijadikan sebagai acuan perkembangan proses pembelajaran pada jenjang yang lebih tinggi. Keberhasilan proses pembelajaran di SD sangat menentukan keberlanjutan studi lanjut siswa. Hal tersebut menjadikan pelaksanaan pembelajaran di SD menjadi sangat urgen dan harus dilakukan dengan baik dan berkualitas agar tujuan pembelajaran yang ingin dicapai dapat terwujud secara tuntas.

Salah satu aspek yang perlu diperhatikan dalam proses pembelajaran di SD adalah penanaman sikap kreatif. Sikap kreatif sangat diperlukan oleh siswa agar mampu menghasilkan inovasi atau ide-ide baru yang akan mendukung kesuksesannya di kehidupan nyata atau di dunia kerja dan dalam penyesuaian diri dengan perkembangan zaman di berbagai era.

Penanaman sikap kreatif dapat diintegrasikan dalam setiap proses pembelajaran. Salah satu mata pelajaran yang dapat diintegrasikan dengan penanaman sikap kreatif adalah mata 
pelajaran bermuatan Ilmu Pengetahuan Alam (IPA). IPA merupakan mata pelajaran yang membekali anak didik ilmu pengetahuan tentang dirinya sendiri, lingkungan alam dan lingkungan sekitar serta bagaimana memelihara, menjaga dan hidup berdampingan dengan alam. Proses pembelajaran yang dilakukan hendaknya dilakukan secara konkret dan mengimplementasikannya langsung dalam proses pembelajaran. Pembelajaran juga dapat dilakukan dengan berbagai eksperimen untuk membuktikan hukum-hukum atau teori yang ada dengan kehidupan nyata sehari-hari. Kegiatan tersebut jika dilakukan dengan sungguhsungguh maka akan meningkatkan sikap kreatif anak.

Strategi yang dapat dilakukan oleh guru dalam mengembangkan sikap kreatif adalah dengan menggunakan ajaran Tri N. Terdapat tiga fase pada ajaran Tri N, yaitu niteni: siswa terlebih dahulu mengamati, memperhatikan dengan saksama arahan dan penjelasan guru tentang subjek yang sedang dipelajari. Niroake: adalah fase guru memastikan siswa sudah memahami dengan baik apa yang disampaikan. Jika siswa tidak dapat meniru, guru perlu memberikan penjelasan ulang agar anak mampu meniru dengan baik apa yang telah dipaparkan. Jika siswa mampu meniru dengan baik pada fase ini, fase niteni terbukti berjalan sesuai tujuan. Fase terakhir dari ajaran ini adalah nambahake. Di sinilah kebebasan siswa dalam berkreativitas ditunjukkan. Jika ketiga fase ini dilaksanakan dengan baik, siswa dapat memiliki sikap kreatif dengan baik. Berdasarkan latar belakang di atas, dilakukan penelitian tentang implementasi Tri $\mathrm{N}$ dalam meningkatkan sikap kreativitas siswa SD.

\section{LANDASAN TEORI}

\section{A. Tri N (Niteni, Niroake, Nambahake)}

Ki Hadjar Dewantara (KHD) merupakan Bapak Pendidikan Indonesia yang memiliki jasa mengubah sistem pendidikan Indonesia dari yang berbasis penjajahan menjadi berbasis nasionalis. Beliau melakukan revolusi pendidikan melalui perguruan Tamansiswa dengan mengimplementasikan berbagai ajaran. Salah satu ajaran yang digunakan dalam proses pembelajaran adalah Tri $\mathrm{N}$. Tri $\mathrm{N}$ merupakan ajaran yang digunakan untuk menumbuhkan kreativitas siswa agar dapat menciptakan hal baru dalam dunia keilmuan sejak dini. Hal ini perlu dikembangkan sebagai cara menempuh ilmu pengetahuan agar tidak asal meniru belaka, dalam arti "menjïlak" atau mengcopy, melainkan harus memasaknya (mengolah) 
segala bahan dari dunia asing untuk dijadikan "masakan baru” yang lezat dan menyehatkan diri. $^{1}$

Niteni adalah proses kognitif atau pikiran manusia, berasal dari kata "titen", yang menunjuk pada kemampuan secara cermat mengenali, dan menangkap makna (sifat, ciri, prosedur, kebenaran) dari suatu objek yang diamati, dengan cara memperhatikan, membandingkan, mengamati secara saksama, jeli dan mendalam serta melibatkan seluruh indra. Diartikan dalam proses berkarya, aktivitas pertama yang dilakukan ialah mengamati, dengan mempelajari masalah, dan menelaah. Mengamati tidak sekadar membaca, melihat, tetapi dicerna, dan diwujudkan dengan baik. ${ }^{2}$ Tindakan niteni fungsi utama dibebankan pada pemikiran. ${ }^{3}$

Niroake, berarti menirukan apa yang telah dipahami, atau tindak lanjut dari proses niteni dengan melibatkan seluruh pribadinya. Niroake adalah aktivitas menirukan dari apa yang dilihat, didengar, dirasakan dalam bentuk contoh atau teladan yang baik. Perilaku meniru ini tidak salah, meniru diartikan sebagai menduplikasi diri terhadap karya yang sudah ada, yang hendak "dicontoh" metodenya, semangatnya, bagaimana mengolah permasalahan menjadi karya yang baik, yang mudah dicerna dan mudah dipahami sesuai fungsinya. Tetapi, bukan hanya sebuah pembiaran dalam praktik plagiarsme, ini adalah proses belajar. Tahapan mengamati merupakan tahapan awal dalam proses terinspirasi yang disebut tahap pengenalan dalam langkah niroake. ${ }^{4}$

Nambahake merupakan sebuah titik akhir, bukan sekadar aktivitas meniru tetapi sudah ada unsur penambahan, suatu aktivitas melengkapi, menyempurnakan sesuai keinginan individu melalui mengolah, mengubah, memodifikasi, menginovasi, memperbaiki, menambah, mengurangi, dan proses berpikir kreatif dalam rangka memunculkan unsur

${ }^{1}$ Ki Hadjar Dewantara. 2013. Pemikiran, konsepsi, keteladanan, sikap merdeka (II) Kebudayaan, Yogyakarta: Majelis Luhur Tamansiswa. Hal:371-372.

${ }^{2}$ IpungKurnianto Yunawan, "Niteni, nirokne, nambahi sebagai proses berpikir kreatif," Jurnal Desain Komunikasi Visual. Vol. 2.N0.2/Oktober 2014.Hal 128.

3Djohar dan Istiningsih. 2016. Filsafat Pendidikan Ki Hadjar Dewantara Dalam Kebidupan Nyata. Yogyakarta: Lentera,.Hal 89

4IpungKurnianto Yunawan, "Niteni, nirokne, nambahi sebagai proses berpikir kreatif," Jurnal Desain Komunikasi Visual. Vol. 2.N0.2/Oktober 2014.Hal 128. 
pembeda, yaitu asas kebaruan. Adakalanya nambahake tersebut dengan tujuan mulia, mewujudkan suatu temuan, atau kemungkinan atas buah makna kebaruan. ${ }^{5}$

Berdasarkan pemaparan di atas, Tri $\mathrm{N}$ yang dimaksud dalam penelitian ini merupakan ajaran yang digunakan untuk menumbuhkan kreativitas anak dengan mengajarkan anak didik untuk mengenali dan menangkap makna dari objek yang diamati dengan cermat mengamati dengan seksama, memperhatikan, membandingkan, mengukur, meraba, mendengarkan secara jeli dan mendalam, struktural, sistematik, holistik serta melibatkan seluruh indera sehingga diperoleh kesan atau persepsi menyeluruh. Pembelajaran juga dilakukan dengan proses meniru dari apa yang dilihat, didengar, dan dirasakan yang dilanjutkan dengan kegiatan penambahan dengan melengkapi, menyempurnakan sesuai keinginan individu dengan mengolah, mengubah, memodivikasi, menginovasi, memperbaiki, menambah, mengurangi, dan proses berfikir kreatif dalam rangka memunculkan asas kebaruan untuk menutupi kekurangan objek yang diamati dan ditiru. Ajaran ini sangat perlu ditanamkan dalam pembelajaran agar siswa dapat menumbuhkan jiwa kreatif dan mampu menciptakan hal yang baru yang dapat diperoleh dari memperhatikan hal yang sudah ada, mengikuti caranya dan kemudian menambahi agar kreativitas yang baru menjadi tumbuh.

\section{B. Kreativitas Siswa}

Kreativitas berasal dari kata kreatif yang berarti bahwa berpikir dan melakukan sesuatu untuk menghasilkan cara atau hasil baru dari sesuatu yang telah dimiliki' ${ }^{6}$ Kreativitas diartikan sebagai ciri khas yang dimiliki oleh individu yang ditandai dengan adanya kemampuan untuk menciptakan sesuatu dari kombinasi karya-karya yang telah ada sebelumnya, menjadi suatu karya baru yang berbeda dengan apa yang telah ada sebelumnya dan dilakukan melalui interaksi dengan lingkungannya untuk menghadapi permasalahan, dan mencari alternatif pemecahannya dengan cara berpikir divergen. ${ }^{7}$

Kreativitas sering digambarkan dengan kemampuan berpikir kritis, mempunyai banyak ide, mampu menggabungkan sesuatu gagasan yang belum pernah tergantung sebelumnya

${ }^{5}$ Ibid.

'Sudarmin. 2018. Pendidikan Karakter, Etnosains dan Kearifan Lokal (Konsep dan Penerapannya dalam Penelitian dan Pembelajaran Sains, Semarang: FMIPA UNNES. Hal 14.

${ }^{7}$ Mohammad Ali dan Mohammad Asrori. 2012. Psikologi Remaja Perkembangan Peserta Didik, Jakarta: P'T. Bumi Aksara, 2012. Hal 42-43. 
dan kemampuan untuk menemukan ide untuk memecahkan permasalahan. ${ }^{8}$ Kreativitas dapat membantu seseorang dalam menjelaskan dan menggambarkan konsep-konsep abstrak dengan melibatkan keterampilan seperti keingintahuan, kemampuan menemukan sesuatu, eksplorasi, dan lain sebagainya yang semuanya merupakan kualitas yang sangat besar bagi siswa. ${ }^{9}$

Indikator dari kreativitas, antara lain, yaitu: (1) memiliki rasa ingin tahu yang besar, (2) sering mengajukan pertanyaan yang berbobot; (3) memberikan banyak gagasan dan usulan; (4) mampu menyatakan pendapat spontan dan tidak malu-malu; (5) memiliki rasa keindahan; (6) mempunyai pendapat sendiri dan tidak mudah terpengaruh orang lain; (7) memiliki rasa humor yang tinggi; (8) memiliki daya imajinasi yang kuat; (9) mampu menyampaikan pemikiran dan gagasan yang berbeda dengan orang lain; (10) dapat bekerja sendiri; (11) senang mencoba hal-hal yang baru; dan (12) dapat mengembangkan suatu gagasan. ${ }^{10}$

Kreativitas yang dimaksud dalam penelitian ini merupakan kemampuan siswa dalam kegiatan pembelajaran yang ditunjukkan dengan: (1) kemampuan siswa dalam melakukan inovasi dengan melengkapi, menyempurnakan, memperbaiki atau menambah dari karya atau ide yang telah ada; dan (2) mempunyai pendapat sendiri dan mampu menyampaikan pemikiran dan gagasannya kepada orang lain.

\section{Pembelajaran IPA di Sekolah Dasar}

IPA didefinisikan sebagai pengetahuan yang diperoleh melalui pengumpulan data dengan eksperimen, pengamatan, dan deduksi untuk menghasilkan suatu penjelasan tentang sebuah gejala yang dapat dipercaya. ${ }^{11}$ Ada tiga kemampuan dalam IPA yaitu: (a) kemampuan untuk mengetahui apa yang diamati, (b) kemampuan untuk memprediksi apa yang belum diamati, dan kemampuan untuk menguji tindak lanjut hasil eksperimen, dan (c) dikembangkannya sikap ilmiah. ${ }^{12}$

8Nurdin Hamzah. 2012. Belajar dengan Pendekatan P AIKEM. Jakarta: PT. Bumi Aksara. Hal 154. ${ }^{9}$ Florence Beetlestone, Creative learning, Bandung: Nusa Media, 2011. Hal 2.

${ }^{10}$ Nurdin Hamzah. 2012. Belajar dengan Pendekatan P AIKEM. Jakarta: PT. Bumi Aksara. Hal 252.

${ }^{11}$ Trianto. 2007. Model pembelajaran terpadu. Jakarta: Prestasi Pustaka Publisher. Hal102.

12Pusat Kurikulum. 2007. Panduan pengembangan pembelajaran IP A terpadu. Jakarta: Balitbang Depdiknas. hal 7. 
Pembelajaran IPA di sekolah dasar dilakukan dengan tujuan agar memberikan bekal kepada siswa tentang pengetahuan tentang diri sendiri, lingkungan, dan alam sekitar. Pembelajaran IPA juga dilakukan agar siswa mampu mengimplementasikan pengetahuan yang telah dimiliki tersebut dalam kehidupan sehari-hari dengan menjaga, memelihara, dan melestarikan alam sekitar. ${ }^{13}$

IPA juga membahas tentang gejala-gejala alam yang disusun secara sistematis yang didasarkan pada hasil percobaan dan pengamatan yang dilakukan oleh manusia. IPA juga berhubungan dengan cara mencari tahu tentang alam secara sistematis sehingga IPA bukan hanya penguasaan kumpulan pengetahuan yang berupa fakta-fakta, konsep-konsep, atau prinsip-prinsip saja tetapi juga merupakan suatu proses penemuan. ${ }^{14}$ Pendidikan IPA di SD diharapkan dapat menjadi wahana bagi peserta didik untuk mempelajari diri sendiri dan alam sekitar, serta prospek pengembangan lebih lanjut dalam menerapkannya di dalam kehidupan sehari-hari. Dalam IPA, dipelajari juga peristiwa-peristiwa yang terjadi di alam, sehingga proses pembelajarannya menekankan pada pemberian pengalaman langsung untuk mengembangkan kompetensi agar menjelajahi dan memahami alam sekitar secara ilmiah.

Kegiatan ilmiah ini diperlukan dalam kehidupan sehari-hari untuk memenuhi kebutuhan manusia melalui pemecahan masalah-masalah yang dapat diidentifikasikan dengan langkah-langkah yang tepat. Penerapan IPA perlu dilakukan secara bijaksana untuk menjaga dan memelihara kelestarian lingkungan. Tingkat SD diharapkan ada penekanan pembelajaran mengenai sains, lingkungan, teknologi, dan masyarakat secara terpadu yang diarahkan pada pengalaman belajar untuk merancang dan membuat suatu karya melalui penerapan konsep IPA dan kompetensi bekerja ilmiah secara bijaksana.

\section{METODE PENELITIAN}

Jenis penelitian ini merupakan penelitian kualitatif deskriptif, yaitu mendeskripsikan implementasi ajaran Tri $\mathrm{N}$ dalam meningkatkan sikap kreatif siswa melalui pembelajaran IPA di SD. Penelitian dilakukan di tiga tempat yaitu di SD Rejowinangun 3, SD

13Sri Sulistyorini. 2007. Model Pembelajaran IP A sekolah dasar dan penerapannya dalam KTSP, Yogyakarta: Tiara Wacana. Hal 40.

14'Trianto. 2007. Model Pembelajaran Terpadu. Jakarta: Prestasi Pustaka Publisher. Hal 99. 
Tamanmuda Ibu Pawiyatan, dan SD Tamansiswa Jetis dengan subjek sebanyak 70 siswa dan tiga guru.

Teknik yang digunakan dalam pengumpulan data antara lain yaitu teknik observasi, rubrik pengamatan sikap kreatif, wawancara, dan dokumentasi. Teknik observasi dilakukan untuk memperoleh data kegiatan implementasi ajaran Tri $\mathrm{N}$ yang dilakukan dalam proses pembelajaran IPA di SD. Instrumen yang digunakan dalam kegiatan observasi yaitu lembar observasi proses pembelajaran dan lembar observasi atau rubrik pengamatan peningkatan aspek kreativitas siswa.

Teknik wawancara dilakukan untuk memperoleh data terkait pelaksanaan implementasi yang dilakukan oleh guru dan siswa. Instrumen yang digunakan dalam kegiatan wawancara yaitu lembar pedoman wawancara yang berisi pertanyaan yang akan ditanyakan kepada guru dan siswa. Teknik dokumentasi dilakukan untuk mengambil data yang diperlukan seperti foto, perubahan dan aktivitas kegiatan kreativitas siswa dalam proses pembelajaran.

Teknik analisis data menggunakan teknik analisis Milles and Huberman yang terdiri dari reduksi data, penyajian data dan penarikan kesimpulan (verifikasi). Data yang terkumpul kemudian dipilih untuk direduksi, kemudian data disajikan dan diberi kesimpulan.

\section{HASIL PENELITIAN DAN PEMBAHASAN}

\section{Hasil Penelitian}

Observasi terkait implementasi Tri $\mathrm{N}$ dalam proses pembelajaran IPA dilakukan dalam tiga kali proses pembelajaran. Proses pembelajaran dilakukan dengan menggunakan Kurikulum 2013, sehingga dilakukan secara tematik. Penelitian ini fokus pada materi yang bermuatan IPA. Aspek kreatif pada pembelajaran 1 diamati dengan indikator: (1) mampu melakukan inovasi dengan melengkapi, menyempurnakan, memperbaiki atau menambah dari karya atau ide yang telah ada, dalam: (a) melengkapi tabel pertanyaan 5W1H; (b) mencari referensi dalam berdiskusi tentang berbagai cara untuk memelihara organ pernapasan; dan (c) berdiskusi membuat model alat pernapasan manusia. 
Indikator kedua dari aspek kreatif adalah (2) mempunyai pendapat sendiri dan mampu menyampaikan pemikiran dan gagasannya kepada orang lain, dalam (a) mengerjakan tabel pertanyaan 5W1H; (b) berdiskusi tentang berbagai cara untuk memelihara organ pernapasan; dan (c) berdiskusi membuat model alat pernapasan manusia. Implementasi Tri $\mathrm{N}$ dalam pembelajaran satu ini adalah guru terlebih dahulu memberikan penjelasan terkait materi tentang berbagai cara dalam memelihara organ pernapasan.

Hasil observasi pada pembelajaran pertama menunjukkan bahwa pada kegiatan ini guru terlebih dahulu memberikan stimulus gambar seseorang yang sedang menghirup udara segar di lingkungan yang bersih. Kemudian guru dan siswa berkomunikasi terkait proses terjadinya pernapasan. Kegiatan dilanjutkan dengan mengamati gambar lingkungan yang bersih dengan lingkungan yang penuh dengan polusi udara. Pengamatan tersebut dilakukan dengan penjelasan tentang ciri-ciri udara bersih dan ciri udara kotor seperti yang terlihat pada gambar. Pada kegiatan ini siswa niteni (mengamati, memperhatikan) apa yang dijelaskan oleh guru.

Pada fase niroake, guru memberikan berbagai pertanyaan terkait materi yang telah disampaikan kemudian siswa menjawab pertanyaan sesuai dengan yang telah dijelaskan oleh guru. Pertanyaan yang diberikan antara lain yaitu: "bagaimana kondisi udara yang ditunjukkan pada gambar (gambar lingkungan yang penuh dengan polusi udara dengan gambar dengan lingkungan bersih)?”. Siswa menjawab pertanyaan menirukan apa yang sudah dijelaskan oleh guru.

Fase selanjutnya adalah fase nambahake, pada fase ini siswa diberi kebebasan untuk menyampaikan ide melalui kegiatan berdiskusi untuk menyampaikan berbagai ide atau gagasan terkait berbagai cara yang dapat dilakukan untuk menjaga atau memelihara organ pernapasan manusia. Hasil observasi menunjukkan bahwa siswa antusias memberikan ide dengan percaya diri. Saat siswa diwawancara setelah proses pembelajaran bagaimana kesan saat proses pembelajaran, salah satu siswa (SS) menjawab:15

"Senang, karena bu guru njelasinnya jelas."

Saat ditanya mengapa berani mengemukakan pendapat, SS menjawab: ${ }^{16}$

"Soalnya kan udab dijelasin dulu sama bu guru, jadi udah paham."

15Surya S, Wawancara. SDN Rejowinangun 3, 24 Januari 2019

${ }^{16}$ Ibid. 
Berdasarkan hasil observasi dan wawancara tersebut, dapat disimpulkan bahwa penjelasan yang jelas dari guru akan menjadikan siswa mudah memahami materi dan membantu siswa mengembangkan ide atau gagasan terhadap materi yang dipelajari. Berikut merupakan hasil rekapitulasi penilaian aspek kreatif pada pembelajaran 1.

Tabel 1. Hasil Rekapitulasi Penilaian Aspek Kreatif Pembelajaran 1

\begin{tabular}{|c|c|c|c|}
\hline \multirow{2}{*}{ Kriteria penilaian } & \multicolumn{2}{|c|}{$\begin{array}{c}\text { Jumlah Penilaian } \\
\text { Tiap Indikator }\end{array}$} & \multirow{2}{*}{ Jumlah Skor } \\
\cline { 2 - 3 } & $\mathbf{1}$ & $\mathbf{2}$ & \\
\hline 4 (Sangat Baik) & 1 & 16 & 17 \\
\hline 3 (Baik) & 52 & 33 & 85 \\
\hline 2 (Cukup) & 17 & 21 & 38 \\
\hline 1 (Kurang) & - & - & - \\
\hline Jumlah Responden & 70 & 70 & \\
\hline
\end{tabular}

Berdasarkan data di atas, dapat disimpulkan bahwa pada pembelajaran satu, sikap kreatif siswa sudah baik. Hal tersebut ditunjukkan bahwa skor yang paling banyak muncul pada penilaian terdapat pada kategori baik yaitu sebanyak 85. Namun, masih terdapat siswa yang masuk dalam kriteria cukup. Hal tersebut dapat tercapai dikarenakan guru memberikan arahan dan penjelasan yang sangat jelas, sehingga mudah dipahami oleh siswa dan siswa mampu menembangkannya saat kegiatan berdiskusi.

Sikap kreatif dalam pembelajaran 2 diintegrasikan melalui kegiatan: (1) mampu melakukan inovasi dengan melengkapi, menyempurnakan, memperbaiki atau menambah dari karya atau ide yang telah ada, dalam: (a) mengisi kolom "Ayo Temukan" untuk menyebutkan ciri gambar cerita; (b) menuliskan cerita dari tema gambar cerita yang telah dipilih; dan (c) membuat poster dengan tema cara merawat organ pernapasan manusia.

Kegiatan kedua yang integrasikan dengan aspek sikap kreatif adalah (2) mempunyai pendapat sendiri dan mampu menyampaikan pemikiran dan gagasannya kepada orang lain, dalam: (a) menyampaikan pendapat saat sesi tanya jawab tentang ciri gambar cerita; (b) menentukan tema dalam pembuatan gambar cerita; dan (c) memberi komentar saat teman lain mempresentasikan poster di depan kelas.

Kreativitas siswa dalam membuat poster pada pembelajaran 2 ini sangat baik. Hasil dari poster yang telah dibuat pun bervariasi yang berisi berbagai cara dalam merawat organ pernapasan. Kegiatan dilakukan dengan guru terlebih dahulu memberikan penjelasan hal- 
hal yang harus diperhatikan dalam membuat poster seperti preposisi isi poster dengan kertas, pemilihan warna, penentuan kalimat dan ketepatan gambar (fase niteni). Pada fase ini guru juga memberikan contoh poster yang baik dan benar.

Fase berikutnya adalah niroake: siswa meniru apa yang sudah dicontohkan oleh guru dan dilanjutkan dengan fase nambahake: siswa diberi kreativitas membuat dan menentukan poster yang dibuat oleh siswa dengan tema cara memelihara organ pernapasan manusia. Berikut merupakan hasil rekapitulasi penilaian aspek kreatif pada pembelajaran 2.

Tabel 2. Hasil Rekapitulasi Penilaian Aspek Kreatif Pembelajaran 2

\begin{tabular}{|c|c|c|c|}
\hline \multirow[t]{2}{*}{ Kriteria penilaian } & \multicolumn{2}{|c|}{$\begin{array}{l}\text { Jumlah Penilaian } \\
\text { Tiap Indikator }\end{array}$} & \multirow[t]{2}{*}{ Jumlah Skor } \\
\hline & 1 & 2 & \\
\hline 4 (Sangat Baik) & 3 & 3 & 6 \\
\hline 3 (Baik) & 50 & 59 & 109 \\
\hline 2 (Cukup) & 17 & 8 & 25 \\
\hline 1 (Kurang) & - & - & - \\
\hline Jumlah & 70 & 70 & \\
\hline
\end{tabular}

Hasil rekapitulasi data di atas menunjukkan bahwa skor terbanyak yang diperoleh dari rubrik pengamatan kreativitas berada pada kriteria baik. Hasil poster yang dibuat oleh siswa sangat variatif.

Hasil wawancara terhadap siswa pada pembelajaran 2 terkait kegiatan pembelajaran yang dilakukan menunjukkan bahwa saat siswa diberi kebebasan untuk berkreasi membuat poster siswa sangat antusias. Saat siswa diwawancara mengapa senang sekali, mereka (ACN dan NAK) menjawab: ${ }^{17}$

"Soalnya disurub buat poster, aku seneng mewarnai sama nggambar."

Hasil wawancara terhadap guru saat melakukan refleksi setelah proses pembelajaran berlangsung, guru juga memaparkan bahwa: ${ }^{18}$

"Anak-anak itu seneng Bu kalo surub nggambar, tapi ya itu, lamaaa."

Hasil dari pembuatan poster dengan tema acara menjaga organ pernapasan manusia sebagai wujud kreativitas siswa dapat dilihat pada tabel berikut.

${ }^{17}$ Afilin Cipta Nurizki dan Nafisah Ayu Kumala,Wawancara, SDN Rejowinangun 3, 1 Februari 2019.

18 Dyah Hediana Windasari, Wawancara,1 Februari 2019. 
Ana Fitrotun Nisa, Zuhdan Kun Prasetyo, Istiningsih, Tri N (Niteni, Niroake, Nambahake) dalam Mengembangkan Kreativitas Siswa Sekolah Dasar

Tabel 3. Contoh Hasil Kreativitas siswa dalam Membuat Poster

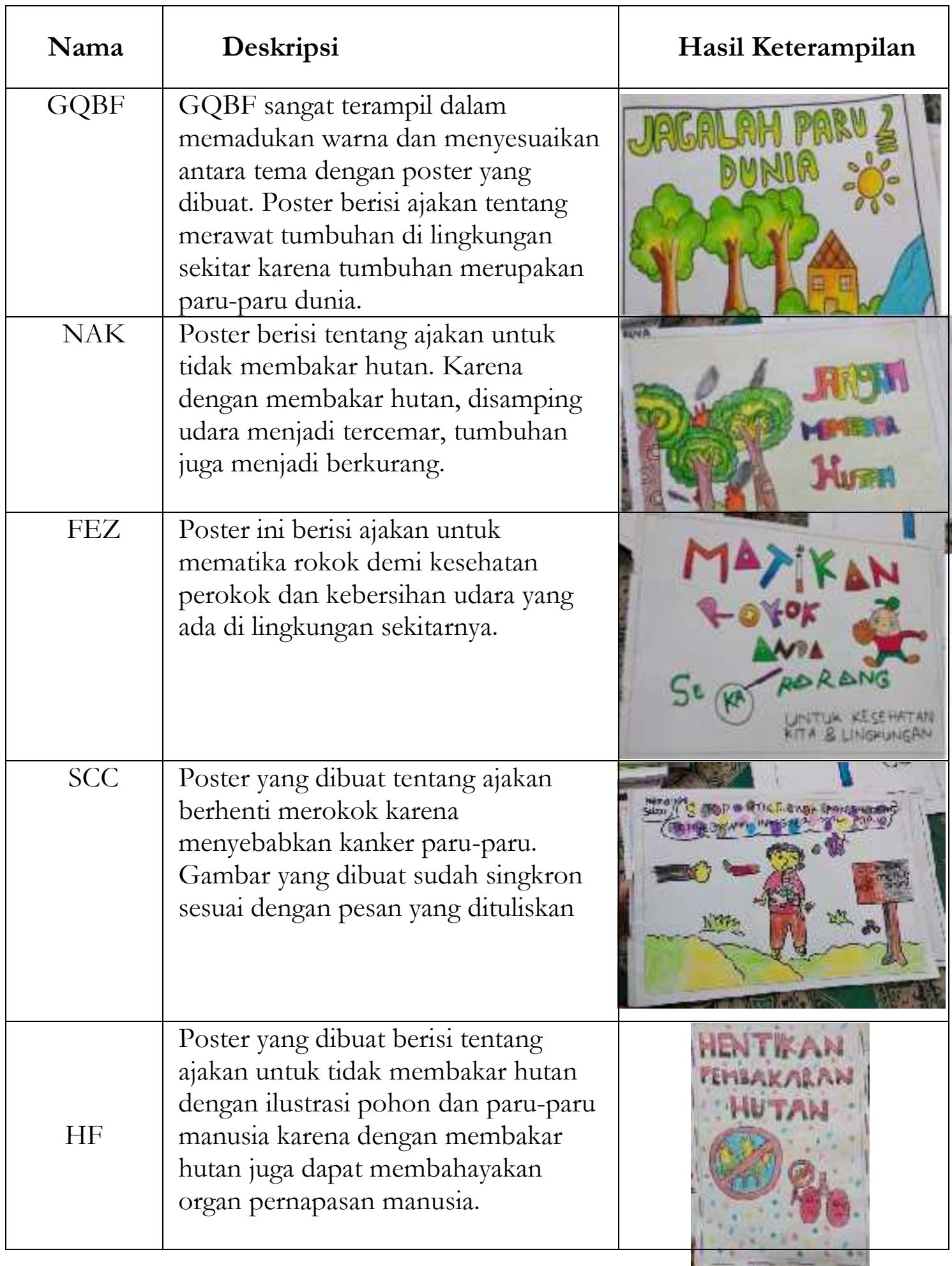

Aspek sikap kreatif pada pembelajaran 3 diintegrasikan dalam kegiatan: (1) mampu melakukan inovasi dengan melengkapi, menyempurnakan, memperbaiki atau menambah dari karya atau ide yang telah ada, dalam; (a) memberikan ide saat memberi warna saat Copyright (c) el-Midad :Jurnal PGMI 2019 
membuat gambar cerita; (b) menyesuaikan cerita dengan gambar yang dbuat dalam gambar cerita; dan (c) mengisi teka-teki silang. (2) Mempunyai pendapat sendiri dan mampu menyampaikan pemikiran dan gagasannya kepada orang lain, dalam (a) menyampaikan pendapat tentang poster yang telah dibuat pada pertemuan sebelumnya; dan (b) menyampaikan pendapat dari gambar cerita yang telah dibuat oleh kelompok lain.

Aspek sikap kreatif yang dikembangkan pada pembelajaran 3 diintegrasikan dengan kegiatan membuat gamber cerita dengan tema memelihara organ pernapasan manusia. Terdapat tiga tema yang disediakan, yaitu: (1) Lingkunganku hijau udaraku bersih, (2) Aku menjaga udaraku bersih, dan (3) Aku merawat kesehatan pernapasan. Daya kreativitas yang tumbuh pada kegiatan ini adalah siswa mampu membuat cerita yang telah mereka pilih. Cerita yang telah dibuat kemudian digambar dan diberi warna sesuai dengan keinginan dan daya kreativitasnya. Kegiatan ini dilakukan dengan terlebih dahulu guru memberikan penjelasan terkait apa itu gambar cerita, apa yang harus diperhatikan dalam membuat gambar cerita dan hal-hal yang menarik dalam membuat gambar cerita (fase niteni).

Fase berikutnya (niroake), siswa meniru dan mempraktikkan apa yang telah dipaparkan oleh guru dan dilanjutkan dengan fase nambahake: siswa diberi kebebasan kreativitas membuat gambar cerita dengan tem acara memelihara organ pernapasan. Berikut merupakan rekapitulasi hasil penilaian aspek kreatif pada pembelajaran 3.

Tabel 4. Hasil Rekapitulasi Penilaian Aspek Kreatif Pembelajaran 3

\begin{tabular}{|c|c|c|c|}
\hline \multirow{2}{*}{$\begin{array}{c}\text { Kriteria } \\
\text { penilaian }\end{array}$} & \multicolumn{2}{|c|}{$\begin{array}{c}\text { Jumlah } \\
\text { Penilaian Tiap } \\
\text { Indikator }\end{array}$} & \multirow{2}{*}{ Jumlah Skor } \\
\cline { 2 - 3 } & $\mathbf{1}$ & $\mathbf{2}$ & \\
\hline 4 (Sangat Baik) & 33 & 54 & 87 \\
\hline 3 (Baik) & 35 & 15 & 50 \\
\hline 2 (Cukup) & 2 & - & 2 \\
\hline 1 (Kurang) & - & - & - \\
\hline Jumlah & 70 & 70 & \\
\hline
\end{tabular}

Berdasarkan hasil rekapitulasi rubrik pengamatan di atas dapat disimpulkan bahwa skor tertinggi ada pada kriteria sangat baik. Hal tersebut berarti bahwa implementasi ajaran Tri $\mathrm{N}$ terbukti dapat meningkatkan sikap kreativitas siswa SD dalam proses pembelajaran IPA. 


\section{Pembahasan}

Implementasi ajaran Tri $\mathrm{N}$ dalam proses pembelajaran dilakukan dengan guru memberikan kebebasan kepada siswa untuk melakukan kreativitas dalam menyampaikan ide atau pendapat. Dalam penelitian ini, penanaman sikap kreatif diintegrasikan dalam kegiatan kreativitas dalam menyampaikan pendapat, membuat poster dan membuat gambar cerita. Pemberian kebebasan kepada siswa ini senada dengan pemikiran KHD yang berbasis kodrat alam anak dengan memerdekakan anak memberikan ide kreativitasnya masingmasing. Dalam fase ini juga diimplementasikan ajaran Tri N (niteni, niroake, nambahake) yang memberikan pembelajaran proses kepada siswa dalam melakukan kreativitas. Hal tersebut senada dengan penelitian yang telah dilakukan oleh Wijayanti yang menyebutkan bahwa ajaran Tri $\mathrm{N}$ terbukti mampu meningkatkan keterampilan dikusi siswa yang meningkat dari siklus 1 sebesar 64\% dan siklus 2 sebesar 67\%. ${ }^{19}$

Siswa juga diberi kebebasan dalam melakukan kreativitas menyampaikan ide atau gagasan, membuat poster dan membuat gambar cerita. Pemberian kebeasan ini juga sesuai dengan teori yang disampaikan Pestalozzi yang menyebutkan bahwa dalam proses pembelajaran anak perlu diberikan kebebasan yang otonom agar tujuan pembelajaran tercapai dengan baik. ${ }^{20}$ Yang dimaksud kebebasan berotonom di sini adalah siswa diberi kebebasan melakukan kreativitas seperti dalam menentukan pesan yang ditulis di poster, menentukan desain warna, menentukan isi cerita dalam gambar cerita, namun hal tersebut tidak keluar dari tema yang telah ditentukan yaitu tentang cara memelihara organ pernapasan manusia.

Pengembangan aspek kreatif bertujuan agar siswa dapat menyesuaikan diri dengan perubahan yang sangat pesat. Hal tersebut penting karena kreativitas merupakan salah satu kompetensi yang harus dimiliki seseorang di Abad Ke-21.21 Kreatif juga merupakan salah satu bekal yang harus dimiliki oleh anak didik agar mampu menghadapi dunia yang cepat

\footnotetext{
${ }^{19}$ Astuti Wijayanti. 2018. The implementation of simulation lecture based on the principles of niteni, nirokke, nambahi (observe, imitate, innovate) to improve the discussion skills of future middle school teacher. Unnes Science Education Journal, 7(03). Hal 272-280.

${ }^{20}$ Soetard, M. 1994. Johann Heinrich Pestalozzi. Prospects: the quarterly review of comparative education. Paris: UNESCO: International Bureau of Education. XXIV, 1(2).hal 297-310.

${ }^{21}$ Shum, S. B. \& Crick, R. D. 2016. Learning analytics for 21st century competencies. Journal of Learning Analytics, 3(2), 6-21. http://dx.doi.org/10.18608/ila.2016.32.2.
} 
berubah. $^{22}$ Kreativitas tidak begitu saja terbangun pada diri anak, namun harus dibangun dan dikembangkan sedini mungkin. ${ }^{23}$

Kegiatan yang dilakukan juga sudah sesuai dengan tahapan perkembangan anak pada umur 9-12 tahun anak dibiasakan untuk melakukan kegiatan yang mengasah kecepatan berpikir serta merasakan dengan halus dan kekerasan kemauan. ${ }^{24}$ Sikap kreatif ini juga menumbuhkan kemandirian siswa karena dengan aktifitas berfikir, menggali ide, dan menyampaikan gagasannya ia ditutut untuk bekerja sendiri, dan memiliki kebaruan dari yang lainnya.

Sikap kreativitas dan kemandirian ini juga berpengaruh terhadap hasil belajar siswa. Hal tersebut senada dengan hasil penelitian yang dilakukan oleh Sulistyarini yang menyebutkan bahwa terdapat pengaruh positif yang signifikan antara kreativitas dan kemandirian siswa terhadap prestasi akademik siswa. ${ }^{25}$ Pengembangan sikap kreatif ini juga merupakan salah satu implementasi dari prinsip merdeka dengan memberikan keleluasaan sesuai dengan kodratnya sendiri tanpa bantuan dari guru. Jika ada kesalahan yang dilakukan oleh siswa barulah guru mengingatkan dan menyampaikan yang seharusnya dilakukan oleh siswa. $^{26}$

\section{SIMPULAN DAN SARAN}

\section{Simpulan}

Berdasarkan pemaparan di atas, dapat disimpulkan bahwa ajaran Tri $\mathrm{N}$ mengembangkan sikap kreativitas siswa SD melalui proses pembelajaran IPA. Pembelajaran dilakukan dengan terlebih dahulu dilakukan fase niteni. Pada fase ini siswa mengamati dan memperhatikan apa yang disampaikan oleh guru terkait subjek belajar yang akan dipelajari. Guru harus menjelaskan dengan baik dan menarik agar siswa dapat memahaminya secara tuntas. Fase selanjutnya adalah fase niroake. Pada fase ini guru

22 Tsai, K. C. 2012. Play, imagination and creativity: a brief literature review. Journal of Education and learning, 1 (2). Hal 15.

23Sit, M., et.al. 2016. Pengembangan Kreativitas Anak Usia Dini Teori dan Praktik. Medan: Perdana Publishing. Hal 1.

${ }^{24}$ Ki Hadjar Dewantara. 2013. Pemikiran, konsepsi, keteladanan, sikap merdeka (I) pendidikan. Yogyakarta: Majelis Luhur Tamansiswa. Hal 468.

25Sri Sulistyorini. 2007. Model Pembelajaran IPA Sekolah Dasar dan Penerapannya dalam KTSP. Yogyakarta: Tiara Wacana.

${ }^{26}$ Ki Hadjar Dewantara. 2013. Pemikiran, Konsepsi, Keteladanan, Sikap Merdeka (I) Pendidikan. Yogyakarta: Majelis Luhur Tamansiswa. Hal. 402. 
Ana Fitrotun Nisa, Zuhdan Kun Prasetyo, Istiningsih, Tri N (Niteni, Niroake, Nambahake) dalam Mengembangkan Kreativitas Siswa Sekolah Dasar

memastikan apa yang disampaikan dapat terserap dengan baik oleh siswa. Jika siswa mampu meniru dengan baik maka fase sebelumnya dianggap sukses, jika belum maka fase sebelumnya perlu diperbaiki atau dievaluasi. Fase terakhir adalah fase nambahake. Pada fase ini siswa diberi kebebasan berkreativitas atas apa yang telah ia pahami dari fase sebelumnya. Saran

Berdasarkan pemaparan di atas, saran yang direkomendasikan agar siswa memiliki sikap kreatif yang baik adalah dengan mengimplementasikan ajaran Tri $\mathrm{N}$ dalam proses pembelajaran. Penanaman sikap kreatif tersebut hendaknya ditanamkan sejak dini agar jiwa kreatif dan kemampuan berinovasi tertanam dengan baik. Guru harus mampu memfasilitasi siswa pada setiap fase nya secara maksimal sesuai dengan karakteristik siswa yang dihadapi.

\section{DAFTAR PUSTAKA}

Ali, Mohammad., Asrori, Mohammad. 2012. Psikologi Remaja Perkembangan Peserta Didik, Jakarta: PT. Bumi Aksara, 2012.

Beetlestone, Florence . 2011. Creative learning. Bandung: Nusa Media.

Dewantara, Ki Hadjar. 2013. Pemikiran, konsepsi, keteladanan, sikap merdeka (II) Kebudayaan, Yogyakarta: Majelis Luhur Tamansiswa.

Djohar., Istiningsih. 2016. Filsafat Pendidikan Ki Hadjar Dewantara Dalam Kehidupan Nyata. Yogyakarta: Lentera.

Hamzah, Nurdin. 2012. Belajar dengan Pendekatan PAIKEM. Jakarta: PT. Bumi Aksara.

Pusat Kurikulum. 2007. Panduan pengembangan pembelajaran IP A terpadu. Jakarta: Balitbang Depdiknas.

Shum, S. B. \& Crick, R. D. 2016. Learning analytics for 21 st century competencies. Journal of Learning Analytics, 3(2), 6-21. http://dx.doi.org/10.18608/jla.2016.32.2.

Sit, M., et.al. 2016. Pengembangan Kreativitas Anak Usia Dini Teori dan Praktik. Medan: Perdana Publishing.

Soetard, M. 1994. Johann Heinrich Pestalozzi. Prospects: the quarterly review of comparative education. Paris: UNESCO: International Bureau of Education. XXIV, 1(2). hal 297310. 
Sudarmin. 2018. Pendidikan Karakter, Etnosains dan Kearifan Lokal (Konsep dan Penerapannya dalam Penelitian dan Pembelajaran Sains, Semarang: FMIPA UNNES.

Sulistyorini, Sri. 2007. Model Pembelajaran IPA sekolah dasar dan penerapannya dalam KTSP, Yogyakarta: Tiara Wacana.

Trianto. 2007. Model pembelajaran terpadu. Jakarta: Prestasi Pustaka Publisher.

Tsai, K. C. 2012. Play, imagination and creativity: a brief literature review. Journal of Education and learning, 1 (2).

Wijayanti, Astuti. 2018. The implementation of simulation lecture based on the principles of niteni, nirokke, nambahi (observe, imitate, innovate) to improve the discussion skills of future middle school teacher. Unnes Science Education Journal, 7(03).

Yunawan, IpungKurnianto. "Niteni, nirokne, nambahi sebagai proses berpikir kreatif," Jurnal Desain Komunikasi Visual. Vol. 2.N0. 2/Oktober 2014. 